\title{
„CZeMu MŁodoścI NIE dAŁ MI BóG, TEJ PŁOCHEJ, LEKKIEJ, SWAWOLNEJ?” — ROZRaChuneK Z żYCIEM w twórczości Mari BartusówNY
}

Młodość to szczególny okres w życiu każdego człowieka, w którym kształtuje się osobowość. To czas poszukiwania autorytetów oraz zderzenia ideałów z rzeczywistością, a także okres bardzo emocjonalnego odbierania świata, pierwszych, gwałtownych miłości i związanych z nimi rozterek. Młodości przypisuje się takie cechy jak odwagę, wrażliwość, zapał, ale i brak rozwagi, doświadczenia oraz skłonność do brawury. Starość jest czasem stopniowego wycofywania się z życiowej aktywności, osłabieniem sił, czasem spokoju, ale także samotności i choroby. Starość symbolizuje dojrzałość, mądrość, doświadczenie i odpoczynek.

Zarówno młodość, jak i starość są istotnymi tematami w twórczości Marii Bartusówny, urodzonej 10 stycznia 1854 roku we Lwowie córki Stanisława Bartusa, malarza portrecisty i Henryki ze Szczepańskich. Ojcem chrzestnym Bartusówny był powieściopisarz Jan Zachariasiewicz. W wieku pięciu lat straciła ojca. Pozbawione z matką środków do życia, przeniosły się do dziadka Jana Juliana Szczepańskiego, który był profesorem i redaktorem. To właśnie obficie zaopatrzona biblioteka dziadka wywarła duży wpływ na osobowość przyszłej nauczycielki. Maria garnęła się do dziadka, unikając towarzystwa babki, ciotek a nawet matki. Słabe zdrowie uniemożliwiało jej uczęszczanie na pensję, do której była zapisana. Dziewczynka zagłębiona w lekturach, żyła oderwana od rzeczywistości, a już w wieku ośmiu lat zaczęła pisać wierszyki, wzbudzające podziw otoczenia. Jednak „cudowne dziecko” nie przywiązywało do nich żadnej wagi, gdyż zaraz zapisane kartki służyły jako papiloty do włosów. Marceli Sławiński dzieciństwo Bartusówny porównał do życia kanarka w klatce. Jego zdaniem, dziewczynka żyła nie zaznając ani uciech, ani przykrości życia i jak uwięziony ptak „wyśpiewywała” zadziwiająco piękne wierszyki (biorąc pod uwagę jej wiek), zrodzone na tle zdarzeń znanych jej z lektur.

Po śmierci Szczepańskiego, Maria wraz z matką i Józefem Preyerem, ojczymem, mieszkała w Roztokach nad Czeremoszem lub u wuja Sławińskiego w Kołomyi. W wieku szesnastu lat próbowała swoich sił poetyckich w piśmie literackim „Jutrzen-

\footnotetext{
* Joanna Jabłońska - absolwentka filologii polskiej oraz logopedii na Uniwersytecie Rzeszowskim. Doktorantka II roku literaturoznawstwa. Strefa jej zainteresowań naukowych to literatura pozytywizmu, komparatystyka oraz teorie feministyczne w literaturze.
} 
ka”. Jego wydawcą był Mieczysław Wąsowicz, który od razu stał się ideałem i jedyną miłością nastoletniej poetki, która tak o nim pisała ${ }^{1}$ :

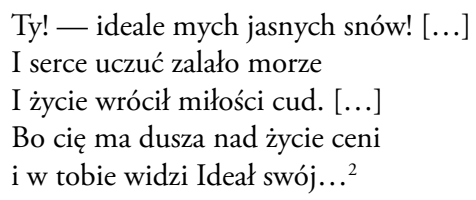

Debiutancki wiersz Bartusówny pod tytułem Trzy obrazy Sybiru wzbudził ogólny zachwyt i przychylną opinię Józefa Ignacego Kraszewskiego ${ }^{3}$. Za główne cechy tego wiersza uznano świeżość, prostotę i urok. W Kołomyi młoda poetka współpracowała z amatorskim teatrem $\mathrm{i}$ była związana ze środowiskiem działaczy społecznych. Następnie potajemnie wyjechała do Lwowa, gdzie pragnęła zostać aktorką. Jednak dyrektor teatru odradził jej karierę ze względu na drobną posturę i słaby głos. O rękę Bartusówny starał się zamożny urzędnik. Sprzyjała mu matka poetki, więc doszło do zaręczyn, które zostały zerwane, gdyż Maria nie darzyła go uczuciem, czego wyraz dała w poemacie Myśli przedślubne. Ukończyła kurs freblowski. Przez dwa lata pracowała w ochronkach. Następnie mieszkała w Warszawie, gdzie współpracowała z Antonim Odyńcem przy redakcji czasopisma „Kronika Rodzinna”. Po zdaniu egzaminu nauczycielskiego, przyjęła posadę wiejskiej nauczycielki w Skolnikach pod Lwowem; następnie przeniosła się do Łazan pod Wieliczką, wreszcie do Nienadowej pod Dubieckiem. Tu rozpoczęła najsmutniejszy okres w swoim życiu, pełen wyczerpującej pracy, nieodpowiadającej jej siłom fizycznym. To czas walki Bartusówny z nędzą i chorobą. W 1882 roku wróciła do Lwowa. Dwa lata później drukiem ukazał się piąty akt dramatu historycznego Wanda oraz poemat o pieśniarzu ludowym Czarodziejska fujarka. Z kolei w 1885 roku wydano opowiadania Duch ruin i Wiazanka konwalii. Kraszewski zachwycony dramatem Wanda wezwał społeczeństwo do materialnej pomocy poetce. Dzięki temu wyjechała na kurację do podgórskiej miejscowości. Było już jednak za późno i po powrocie zmarła na ręku matki 2 października 1885 roku, mając zaledwie 31 lat $^{4}$.

Motyw młodości w poezji Bartusówny wiąże się z problemem miłości młodzieńczej, najpełniej wyrażonym w cyklu dwunastu sonetów, napisanych w 1874 roku, zatytułowanych Myśli przedślubne. Utwory te są uznawane za jedne z najlepszych, jakie napisano $\mathrm{w}$ Polsce w drugiej połowie XIX wieku ${ }^{5}$ Zdaje się, że sonety są wierszami autobiograficznymi, gdyż nie znając życiorysu poetki nie sposób zrozumieć wielu ich fragmentów.

\footnotetext{
${ }^{1}$ Zob. A. Stodor, Szkic biograficzno-literacki, [w:] M. Bartusówna, Dzieta, t. 1, Lwów 1914, s. 5-11.

${ }^{2}$ M. Bartusówna, Do ${ }^{* * *}$, [w:] A. Stodor, dz. cyt., s. 27, w. 2, 11-12, 19-20.

${ }^{3}$ J. A. Mikulski, Maria Bartus (poetka nauczycielka) sylwetka literacka, Kraków 1908, s. 7.

${ }^{5}$ A. Brodzka, Maria Bartusówna 1854-1885, [w:] Literatura polska w okresie realizmu i naturalizmu, Warszawa 1965, „Obraz Literatury Polskiej”, ser. 4, t. 1, s. 357-365.

${ }^{5}$ J. Tomkowski, Safona w szkole, [w:] Samobójcy i marzyciele: O zabijaniu poetów, Kielce 2002, s. 216.
} 
Wiersze te nie traktują o często opisywanej w literaturze niechęci do małżeństwa z niekochanym człowiekiem, ale o ogólnej niechęci do samej instytucji małżeństwa ${ }^{6}$. Oto jak poetka wyrażała się o dniu ślubu:

Jedna chwila... i słowo straszliwe „na wieki”
Łączące dwoje istot ciężkimi łańcuchy
Zimnego obowiązku — usłyszy lud tłumny...

Na wieki! — szepną blade moich wspomnień duchy,

Odlatując na zawsze - w świat mroczny... daleki...

I wywiodą mnie znowu... Czemuż nie do trumny?!?

Jak zauważa Jan Tomkowski, cykl Myśli przedślubne zaskakuje odwagą, szczerością oraz oryginalnością metafor. Podważa silnie utrwalony w dotychczasowej literaturze stereotyp, uważający ceremonię ślubu, wesela, a niekiedy i nocy poślubnej za uroczystość radosną, dającą przede wszystkim powody do satysfakcji kobiecie ${ }^{8}$.

W sonetach stosunek do instytucji małżeństwa jest zdecydowanie odmienny od obowiązujących konwenansów. W tych utworach wybrzmiewa nie tylko sprzeciw wobec uwięzienia duszy, ale krzyk oznajmujący, że narzucone postępowanie jest niezgodne z jej światopoglądem. Drogę Bartusówny do napisania cyklu Myśli przedślubne otwiera nieodwzajemniona miłość do Wąsowicza, a następnie zaręczyny z niekochanym mężczyzną.

W cyklu sonetów kobieta została skazana, osaczona i postawiona w sytuacji bez wyjścia. Musiała ulec swojemu przeznaczeniu, poddać się oczekiwanej przez otoczenie ceremonii, której następstwem stała się utrata wolności i nadziei ${ }^{9}$. Adresatem wypowiedzi jest Bóg. Cały cykl ma charakter spowiedzi, zdaje się, że ostatniej. Przedślubne wyznanie porównane zostało do modlitwy Chrystusa w Ogrójcu. I tak oto wieniec panny młodej staje się koroną cierniową, weselny pochód gości — orszakiem pogrzebowym, słowa przysięgi - więziennymi łańcuchami. Wyobraźnia dwudziestoletniej poetki odkrywa zaskakujące powiązania pomiędzy symbolami uroczystości ślubnych, niewątpliwie związanych z czasem młodości a śmiercią, kojarzoną z ostatnim etapem życia człowieka. Otóż biel sukni ślubnej przypomina biel cmentarnych posągów, droga prowadząca do ołtarza drogę prowadzącą do trumny. Miłość nie kojarzy się z namiętnością, wybuchem wielkich emocji czy pożądaniem. Jest raczej pojednaniem i spokojem:

O, miłości! Tyś nie jest bachantką szaloną

Ani maską kryjącą ludzkie cele brudne,

Lecz gołębiem z oliwną gałązką zieloną,

\footnotetext{
${ }^{6}$ G. Borkowska, Pozytywiści i inni, Warszawa 1996, s. 187.

${ }^{7}$ M. Bartusówna (Maria B.), Myśli przedślubne, [w:] taż, Poezje, Lwów 1876, s. 18, w. 9-14.

${ }^{8}$ J. Tomkowski, dz. cyt., s. 217.

${ }^{9}$ Tamże.
} 
[...] O, miłości!

A jednak tyś dla mnie straconą... ${ }^{10}$.

Nad całym cyklem unosi się nastrój infernalny. Świat przypomina piekło, jest ciemno i cicho. To miejsce przepełnione obłudą, zdradami, zawiścią i wieczną walką. Nikt nie odpowiada na jęk uwięzionej duszy:

A tyle wre błagania w każdem majem słowie!

A rozpacz ma tak darmo współczucia przyzywa!

Tylko może gdzieś w cieniach płaczą Aniołowie! ${ }^{11}$

Podmiot liryczny w swoim cierpieniu jest osamotniony, jedynymi świadkami dramatu są aniołowie. Pojawia się nawet zwątpienie w istnienie Boga. Kobieta zaznaczyła, że poświęciła się dla matki, bo ciąży na niej obowiązek zapewnienia jej bytu. Tylko z tego powodu musiała żyć "niosąc spokojnie łańcuch niewolniczej doli” ${ }^{12}$. Alter ego poetki pragnęło snu, w którym spełniają się marzenia. Przyszłość jawi się jako „smutna, zimna, surowa i naga, odarta z wszelkich złudzeń pozłacanej szaty” ${ }^{13}$. Po raz ostatni odniosła się do swojego serca, bo małżeństwo to czas, kiedy będzie go pozbawiona. Czasem bez miłości, okresem panowania chłodu i pustki emocjonalnej, będą to „zimne przyszłości pustynie” 14 . Przyszły mąż wzbudzał w niej pogardę. Pisała: „Bierzesz tylko me ciało, lecz nie weźmiesz duszy!”" Jak zauważyła Kamila Tuszyńska małżeństwo i współżycie z niekochanym mężczyzną, było dla Bartusówny formą gwałtu i powodem poniżenia ${ }^{16}$. Wyraźnie sprzeciwiała się sprzedawaniu siebie dla pieniędzy. Przerażała ją świadomość, że do zawarcia małżeństwa wystarczy „cielec złoty”, że miłość można kupić. Prawdziwa miłość w ówczesnym świecie nie miała racji bytu. Bartusówna pielęgnowała w duszy pamięć o miłości, której kiedyś doświadczyła. Zapewne chodziło o uczucie do Wąsowicza. Mówiła: „Widziałam cię przy sobie od dni moich świtu!" ${ }^{17}$. Tamta miłość była "posłanką niebiosów”18 - miłością czystą, świętą i wielką. Jednak niezrozumiałą przez innych, uznających kobietę za szaloną, o czym świadczyły słowa: „A ludzie mnie trwożnymi ścigali oczyma” ${ }^{19}$.

Sonet $\mathrm{V}$ poetka uczyniła osią całego cyklu. To w nim mowa jest o niechcianym ślubie:

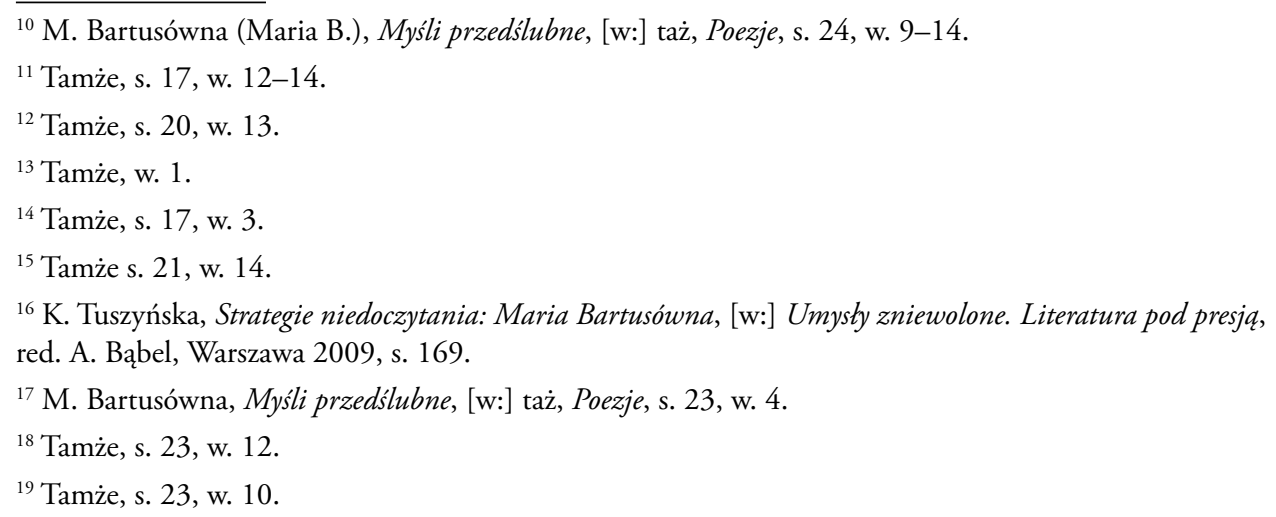


Wkrótce zielony wieniec upną mi u czoła,

Ślubna zasłona skryje wypłakane oczy,

Orszak strojnych, wesołych rówieśnic otoczy

I powiedzie w rozwarte podwoje kościoła ${ }^{20}$.

$\mathrm{Na}$ jego podstawie mówiono o zawartym już ślubie. W końcu utwór przenosi odbiorcę w realia ceremonii ślubnej: wianek, welon, druhny, kościól, muzyka organowa i słowa przysięgi. Jednak nie jest to stereotypowe pojmowanie momentu ślubu. Tutaj przysięga małżeńska połączyła „dwoje istot ciężkimi łańcuchy” ${ }^{21}$ i wywołała u panny młodej marzenia o śmierci. Sonety przedstawiają konflikt wewnętrzny młodej dziewczyny. Po jednej stronie występuje konwenans i obowiązek, jakim jest zapewnienie bytu materialnego dla siebie i matki. Po drugiej zaś wartości, specyficzne dla czasu młodości: wolność, miłość, indywidualne poczucie szczęścia jednostki ${ }^{22}$.

W liryce autorki Myśli przedślubnych dominuje wspomnienie miłości bezpowrotnie utraconej, przeważa nastrój smutku i zwątpienia, który został wyrażony w wierszu $Z a$ późno:

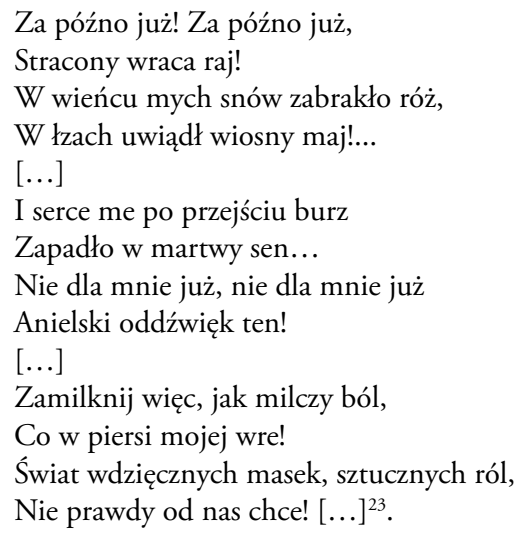

Słowami „w wieńcu mych snów zabrakło róż” Bartusówna wyraziła brak szczęścia w swoim życiu, gdyż jak pisał Ireneusz Sikora, róże są kwiatami szczęścia i to szczęścia o charakterze erotycznym. Wielowiekowa tradycja i powszechna praktyka poetycka spowodowały, „że właśnie ten kwiat stał się uniwersalnym ekwiwalentem obrazowym uczucia miłości”" Słowa „w łzach uwiądł wiosny maj” sugerują, że beztroski czas młodości dobiegł końca. Tak często pojawiające się w lirykach poetki martwe kwiaty

${ }^{20}$ Tamże, s. 18, w. 1-4.

${ }^{21}$ Tamże, s. 18, w. 10.

${ }^{22}$ Zob. T. Budrewicz, Nim na dziewczynę zawołają: żono!...: Marii Bartusówny „Myśli przedślubne”, [w:] Zapomniani pisarze, zapomniane książki dla matego i mtodego czytelnika, red. Krystyna Heska-Kwaśniewicz, Katowice 2005, s. 35.

${ }^{23}$ M. Bartusówna, Za późno, [w:] taż, Dzieła, s. 39, w. 8-27.

${ }^{24}$ I. Sikora, Symbolika kwiatów w poezji Młodej Polski, Szczecin, 1987, s. 44. 
symbolizują przemijanie życia ludzkiego ${ }^{25}$. Osoba mówiąca w wierszu, tak jak sama autorka, jest rozczarowana młodzieńczą miłością. Miejsce miłości w sercu bohaterki zajęły teraz sarkazm i obojętnośćc ${ }^{26}$. Ogromne cierpienie kobiety potęgowało poczucie samotności. Zdaje się, że nieszczęście, które ją spotkało spowodowane jest tym, iż została opuszczona przez swojego Anioła Stróża:

O gdzieżeś gwiazdo przewodnia

Młodości mojej natchnienia!

O gdzieżeś!... szukam cię co dnia,

Gdzie leżą perły wspomnienia,

I zgasła twoja pochodnia! ${ }^{27}$

Aniołowie są posłańcami Boga, opiekunami powierzonych im osób, zanoszą ludzkie modlitwy przed oblicze Boga, pomagają podjąć właściwą decyzję. Dlatego opuszczona przez swojego stróża kobieta nie potrafiła odnaleźć się w otaczającej ją rzeczywistości.

W swoich utworach poetka dokonała rozrachunku z życiem, najpełniej wyrażonym w utworze Czemu?:

Czemu młodości nie dał mi Bóg,

Tej płochej, lekkiej, swawolnej?

Którą choć zrani cierń albo głóg,

Wnet kwiatek pocieszy polny?

Czemu tych cacek nie dał mi Bóg,

Co się zwą szczęściem na ziemi?

Lecz powiódł torem dziwnych dróg,

Za ognikami błędnymi? ${ }^{28}$

Cały wiersz zdaje się być skargą, skierowaną do Boga, w której podmiot liryczny wyraził swoje nieszczęście.

Młodość symbolizuje czas radości, szaleństwa, beztroski, niekiedy głupoty. Jednak zupełnie inaczej jawiła się w twórczości Marii Bartusówny. Otóż jej młodości nieustannie towarzyszyło cierpienie, pesymizm i zwątpienie. Żyje w świecie, w którym ideały były tylko „szałem” młodości, a liczyły się jedynie dobra materialne. Pisanie o uczuciach wiązało się z odwoływaniem przez poetkę do pór roku i zestawieniem nastroju podmiotu lirycznego z przemianami zachodzącymi w przyrodzie, szczególnie wiosennej i jesiennej ${ }^{29}$. Wiośnie, symbolizującej młodość przypisane zostały marzenia, nadzieja i radość:

${ }^{25}$ W. Kopaliński, Stownik symboli, wyd. 2, Warszawa 1990, s. 184.

${ }^{26}$ Zob. E. Kozłowska, „Smutna nade mna gwiazda świecita... ” Główne motywy twórczości lirycznej Marii Bartusówny, [w:] Literatura i jej konteksty. Prace ofiarowane Profesorowi Czesławowi Kłakowi, red. J. Rusin, K. Maciąg, Rzeszów 2005, s. 166.

${ }^{27}$ M. Bartusówna, Nie ma mojego anioła, [w:] taż, Dzieła, s. 25, w. 10-15.

${ }^{28}$ M. Bartusówna, Czemu?, [w:] taż, Dzieła, s. 37, w. 1-8.

${ }^{29}$ E. Kozłowska, dz. cyt., s. 161. 
Wiosna! Wiosna się budzi!... Ile szumów i gwarów

W leśnej znowu rozlega się głuszy,

Tyle marzeń i rojeń, tyle dziwów i czarów,

W głębiach mojej odzywa się duszy!

Myśli tęskne i błogie w ciągłej z sobą rozterce

Kłótnię wiodą bez końca różową...

O! mój Boże! — więc prawda, że i zmarłe to serce,

Budzisz wiosną miłości na nowo? ?0 $^{30}$

Rodząca się do życia przyroda napawała bohaterkę utworu radością. To jeden $\mathrm{z}$ nielicznych wierszy nacechowanych pozytywnymi emocjami $\mathrm{w}$ dorobku autorki Myśli przedślubnych.

Starość określona została jesienią życia. I to właśnie jesień w poezji poetki, tak jak starość, kojarzona jest ze smutkiem, zwątpieniem, samotnością, bólem i śmiercią:
Ale po wiośnie jesień zawitała. -
Powiędły kwiaty, znikły czary — wonie,
Niebo schmurzyła, uroki rozwiała,
Pożółkłym liściem zasypała błonie!
$\mathrm{O}$, znacie jesień tę tyrańską, srogą,
Nieprzyjaciółkę szczęścia i piękności,
Co niszczy wszystko, nie szczędząc nikogo,
Depcze nadzieje bez żadnej litości... ${ }^{31}$.

Już w wierszu Zwątpienie, bohaterka wyraziła tytułowe zwątpienie w sens życia, w którym nie dopatrzyła się żadnych przyjemności. Stała się obojętna na świat do tego stopnia, że nie czuła nawet bicia swego serca, a jedynie ,życia gorycz i mękę"32. W wierszu Wspomnienie podmiot liryczny mówi o tajemnej sile ciążącej nad własnym losem:

Nie dla mnie szczęście! — Gdym się rodziła,

Smutna nade mną gwiazda świeciła, -

Wierną jej muszę być! ${ }^{33}$

W wierszu Sierota przedstawiona została sylwetka dziewczynki, będącej symbolem zarówno młodości, jak i starości. Stojąca wśród grona dzieci, wyróżniała się bladą twarzą i żałobną sukienką. $Z$ twarzy pełnej dziwnego uroku, można wyczytać jej nieszczęśliwą przyszłość. Dziewczynka miała: „Twarz tak młodą - a starą cierpieniem!”34. Uczestniczyła ona w pogrzebie swojej matki. W dalszych partiach tekstu ukazano przyszłość sieroty porównanej do pisklęcia wyrzuconego z gniazda. Bez pomocy innych, dziewczynka:

\footnotetext{
${ }^{30}$ M. Bartusówna, Wiosna, [w:] taż, Dzieła, s. 106, w. 26-33.

${ }^{31}$ Taż, Wiosna i jesień, [w:] taż, Dzieła, s. 84, w. 17-24.

${ }^{32}$ Taż, Zwątpienie, [w:] tamże, s. 43, w. 11.

${ }^{33}$ Taż, Wspomnienie, [w:] tamże, s. 7, w. 28-30.

${ }^{34}$ Taż, Sierota, [w:] taż, Poezje, s. 46, w. 24.
} 
Skona z żalu, którym serce pęka!

Lub co gorzej, będzie w długie lata,

Wlokła życia ciężkiego kajdany,

Żebrząc darmo miłości u świata ${ }^{35}$.

Dziewczynka w wiośnie swojego życia została naznaczona śmiercią bliskiej osoby, co odbije się na całym jej życiu. Szczęśliwy dla niej czas młodości dobiegł końca. Świadczą o tym słowa: „A myśli te, to już nie sen / Jasny, różowy, młodych lat!...” ${ }^{36}$. Jej marzenia „pierzchły jak poranne mgły" $37 \mathrm{i}$,rozpłynęły się we łzy” ${ }^{38}$, a „serce zapadło w martwy sen"39. Swoisty rozrachunek z życiem wystąpił w utworze Odpowiedź, mającym formę rozmowy. Na pytanie świata i Boga: „Czylim kochała?”40, odpowiedzi może udzielić jedynie: zwiędły życia kwiat, smutku mrok, żałobny dzwon i cichy grób pod cieniem brzozy $^{41}$. Bezradny w tej sytuacji był także, towarzyszący jej anioł młodości, który:

Stał przy niej łzawy cierpieniem,

Złote sny szczęścia, miłości,

I wdzięczne mary przeszłości

Żegnał westchnieniem! ${ }^{42}$

Występujący w utworach poetki motyw starości podkreśla między innymi dominująca w jej wierszach kolorystyka z przewagą szarości i czerni oraz atrybuty, symbolizujące śmierć, a także pojawiające się niezwykle często płaczące lub umarłe anioły. Słowem — kluczem zdaje się być smutek. Autorka posługiwała się następującymi wyrażeniami: „dnie smutne”, „smutne marzenia”, „smutna podróż”, „smutna gwiazda”. Opiewanie smutku, zniechęcenia, rozpaczy zdaje się być rejestrem stanów psychicznych kobiety skazanej na „sierocą dolę”, a także wynikiem przemyśleń poetki dotyczących jej własnej egzystencji, co tłumaczyłoby tak częste podejmowanie tematu śmierci, która jawiła się jako kres tragicznego losu, wybawienie od cierpieńn ${ }^{43}$. Niejednokrotnie w lirykach tej poetki pojawiło się przeczucie nadchodzącego kresu życia:

Idę, idę do końca

Moją drogą samotną -

Bliski już zachód słońca -

Życie - chwilką przelotną ${ }^{44}$.

${ }^{35}$ Tamże, s. 46-47, w. 36-39.

${ }^{36}$ M. Bartusówna, (Maria B.), W samotności, [w:] taż, Poezje, s. 50, w. 6.

${ }^{37}$ Tamże, w. 9.

${ }^{38}$ Tamże, w. 11.

${ }^{39}$ Tamże, s. 53, w. 2.

${ }^{40}$ Taż, Odpowiedź, [w:] tamże, s. 114, w. 1.

${ }^{41}$ Tamże, w. 8-10.

${ }^{42}$ Taż, Nie ma mojego anioła, [w:] tamże, s. 61, w. 18-21.

${ }_{43}$ Zob. E. Kozłowska, dz. cyt., s. 171.

${ }^{44}$ M. Bartusówna, Idę, idę do końca, [w:] taż, Dzieła, s. 60, w. 1-4. 
Pogodzenie się z losem i przeczucie nadchodzącej śmierci oraz odwaga w jej obliczu, ale także wątpienie w życie pozagrobowe najpełniej wyraził utwór Do śmierci!, ogłoszony bezpośrednio po śmierci poetki:

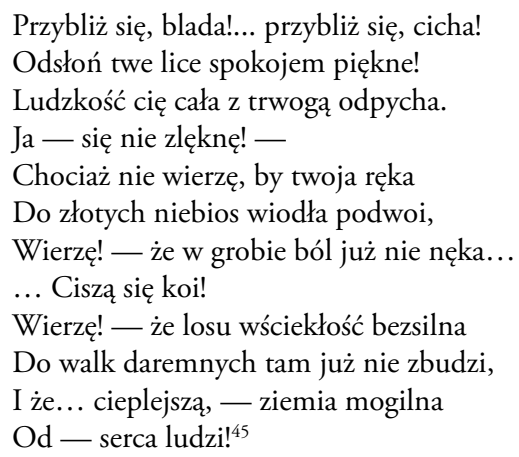

Na pesymistyczny nastrój jej poezji mogły mieć wpływ negatywne oceny współczesnych pisarzy, zarzucających młodej poetce brak zainteresowania problematyką przemian społecznych. Tymi słowami wyraziła się o jej poezji Maria Konopnicka:

Nazywa się wprawdzie poetka „dziecięciem wieku”, ale na całej przestrzeni tych liryk stoi w stosunku do epoki swojej raczej w charakterze świadka niż uczestnika wielkich jej porywów. Owszem, ona się lęka o tych, którzy idą na naprzód [...] Zagadnienia ogólniejszej natury zajmują poetkę w nieznacznej stosunkowo mierze. [...] Przed smutkiem własnym — świata szerszego i wszechludzkich bólów nie spostrzega; opłakuje nie to, co jest gwałtem i krzywdą, ale to, co leży w porządku natury rzeczy, jak sieroctwo, zwiędłe kwiaty i rozwiane liście złudzeń ${ }^{46}$.

Maria Bartusówna w swoich utworach wybiera dyskretne uogólnienia, unika konkretów. Pozostawia zagadkowe i subtelne opisy stanów psychicznych, nastroje i symbole $^{47}$. Te wszystkie zabiegi zbliżają jej twórczość raczej do poetyki modernistycznej niż pozytywistycznej.

Zarówno w cyklu Myśli przedślubne, jak i w utworach z tomu Poezje, motywy młodości i starości przeplatały się. W twórczości tej przedwcześnie zmarkej poetki możemy dopatrzeć się niemal wszystkich problemów związanych z wiosną i jesienią życia. Nie dane było jej doświadczyć okresu starości, ale wydaje się, że Bartusówna tak, jak bohaterka wiersza Sierota, została naznaczona starością w wieku młodzieńczym, gdyż jej młodości towarzyszyło nieustanne cierpienie, spowodowane śmiercią bliskich osób, nieszczęśliwą miłością, niemożnością zrealizowania swoich marzeń, problemami materialnymi i ciężką chorobą, doprowadzającą do śmierci w młodym wieku.

\footnotetext{
${ }_{45}$ Taż, Do śmierci, [w:] tamże, s. 79.

${ }^{46}$ M. K[onopnicka], Maria Bartusówna, „Świt” 1885, nr 81, s. 116-117. Cyt. za: A. Brodzka, dz. cyt., s. 362.

${ }^{47}$ Zob. J. Tomkowski, dz. cyt., s. 216-217.
} 
Joanna Jabłońska

\title{
"WhY YOUTH DID NOT GIVE ME GOD, THE REED, LIGHT, WANTON?" \\ - Settlement Life in the Works of Maria Bartusówna
}

\begin{abstract}
Summary
The problems of youth and old age are important motives in the works of Maria Bartusówna. Youth, symbolising a time of joy, madness, carelessness, sometimes stupidity in the works of the deceased at the age of 31 years the poet is seen as a time of suffering, pessimism and doubt. Autumn, as old age is associated with sadness, despair, loneliness, pain and death. In a series of sonnets entitled Prenuptial Thoughts Bartusówna presented the internal conflict of a young girl. On one side there is a convention and the duty to ensure the material existence for himself and his mother. Among the values specific to the time of youth there are: freedom, love, happiness individual units. In both cycle of Prenuptial Thoughts and songs from volume Poems motives of youth and old age are interweared. It seems that the poet was marked by the problem of the old age in adolescence, because of her youth accompanied by incessant suffering caused by the death of loved ones, unhappy love, the incapability to realise her dreams, financial problems and severe disease causing death at a young age.
\end{abstract}

Słowa kluczowe: rozrachunek, młodość, starość, smutek

Keywords: settlement, youth, old age, sadness 